\title{
LAW OF THE DANCE: LEGAL AND REGULATORY FRAMEWORK FOR PROMOTING APPROPRIATE MUSIC CONTENT IN NIGERIA
}

\author{
Augustina T. Clark*
}

\begin{abstract}
7 he Nigerian music industry has evolved from humble beginnings. It

has witnessed a rapid ascendance from ancient cultural songs based on the norms and customs of the people around where the music emanated, to a global multi-billion-naira industry. The industry is largely regulated by the National Broadcasting Commission, National Film and Video Censors Board, and the Copyright Protection laws and other interest bodies. These institutions have statutory roles to review and censure music contents that overstep or collide with cultural, legal, ethical or intellectual property requirements or norms. However, the recent rise in the rate of release and production of lewd, inappropriate and culturally incompatible music contents in the Nigerian music industry have generated calls for a closer review of how regulatory institutions can be strengthened to effectively address the negative impacts of contemporary music on Nigerian laws and norms, especially among youths. This article evaluates the roles of law in regulating the contemporary music industry in Nigeria to ensure coherence and compatibility with ethical, legal and cultural norms. It analyses how current regulatory institutions in Nigeria can be strengthened to effectively discharge their regulatory roles of ensuring the appropriateness of music content for the good of the Nigerian society.
\end{abstract}

Keywords: Music, appropriate content, videos, lyrics, effects, youths, culture.

doi: http://dx.doi.org/10.4314/jsdlp.v6i1.13

* LLB (Benin), BL (Abuja), LLM (Ibadan), Doctoral Candidate (Unilorin), Member (DCON) (Professional Negotiator and Arbitrator).

Contact: tobotina@yahoo.com; clarkau@abuad.edu.ng; 08023598075; 07061648378. 


\section{INTRODUCTION}

$\mathrm{M}$ usic has been in existence for centuries. People often feel connected to music, and the effects of such connections can be positive or negative. The Oxford Dictionary defines music as "the art of combining vocal or instrumental sounds (or both) to produce beauty of form, harmony, and expression of emotion". ${ }^{1}$ Various combinations of sounds have evolved, over the years, into recognized genres of music that send out different kinds of messages ranging from love, peace, freedom, violence, to anger. Across the world, and in varying degrees, music has been integral to rebellion, resistance and revolution. For example, during the 2011 uprisings in Libya, protesters pumped loud music from radios or CD players in the streets in front of government buildings, to stimulate them to press further in the struggle. The nonviolent early days of Egypt's revolution also witnessed the use of music by the protesters to convey their disagreement with the government. In Turkey, the "Song of Pots and Pans" exhorts political leaders to stop their lies and repressive tactics. ${ }^{2}$ Music, therefore, has primordial roles in providing non-violent basis for the attainment of sustainable development, peace and smooth running of the society.

In Nigeria, several musicians have over the years used music to evaluate and criticize government actions and programmes, and have in the process served as gatekeepers in sensitizing the public to the challenges of sustainable development in the Nigerian society. The resounding impacts of Fela Anilukapo Kuti's "Beast of No Nation", "International Thief-Thief (ITT)” and Eedris Abdulkareem's "Nigeria Jaga Jaga” tunes, easily highlight the strategic power of dance and melody in inspiring societal development in Nigeria, most especially in providing effective alternatives to violence in the demand for governmental action.

Arts, music and culture are, therefore, powerful amplifiers of nonviolent action and peace building, when the contents are attuned to the

1 Music has also been defined as the art of arranging sounds in time as to produce a continuous, unified, and evocative composition, as through melody, harmony, rhythm, and timbre; however, music is much more than this. See generally, Oxford English Dictionary (Oxford University Press 2015)

2 United States Institute for Peace, "Music Plays Crucial Role in Non-Violent Civic Movements” <www.usip.org/olivebranch/music-plays-crucial-role-in-nonviolent-civic-movements> accessed 25 July 2015. 
prevailing needs of the society. ${ }^{3}$ Appropriateness of content is situation driven; what is appropriate for one country may not be appropriate for another. Even at the national level, what is appropriate in the bustling and more cosmopolitan Lagos State, for instance, may be conservatively viewed in Oyo State or in Nasarawa State. Simply put, the Nigerian society is the principal determinant of what represents "appropriate content" in the context of musical production in Nigeria. Reform messages are transmitted through a chain that begins with lyrics by the musician; beats from the producer; review by the regulatory body who approves it; approval by the media houses who air it; acceptance by the corporate bodies who endorse it and use music in their brands; the parents and guardians of the youths who condone it; the religious bodies who do not preach against it; and finally the youths who enjoy it. Evidently, from this chain, every song that plays in Nigeria is arguably an attestation to the prevailing ethical, social, cultural and religious norms in Nigeria. Appropriate content simply refers to the compatibility and suitability of music to the overall legal, social, environmental, economic and technical requirements of the country.

One may wonder what law has to do with music which generally comes under the deliberations of liberal arts, and constitutes a very informal aspect of the society. Law provides normative frameworks for enforcing appropriate content in music production. The laws of any society do not only stand to set up legal entities, but also to safeguard the society in which the law operates. The influence of music on the society emphasizes the important role of law in adequately regulating the contents of what is produced and disseminated to ensure appropriateness. ${ }^{4}$

In recent times, however, the Nigerian entertainment industry has witnessed a geometric rise in the production and dissemination of

3 Erica Chenoweth and Maria J. Stephan, Why Civil Resistance Works: The Strategic Logic of Nonviolent Conflict (Columbia University Press, 2011) 2-5.

4 The National Drug Law Enforcement Agency (NDLEA) in Nigeria in June 2015 invited Davido a Nigerian musician over the content of the video of his music titled Fans Mi for substance suspected to be narcotics, see "Davido in NDLEA Trouble" <http://newtelegraphonline.com/davido-in-ndlea-trouble/> accessed 28 June 2015. Also an article in Punch Newspaper reported that NDLEA had on 28 June 2013, said controversial Nigerian actress, Tonto Dikeh, risked a minimum of 15 years in jail for encouraging the consumption of hemp, as mentioned in a related article to that of Davido, see "NDLEA set to probe Davido over Video" $<$ www.punchng.com/news/ndlea-sets-to-probe-davido-over-video/> accessed 30 July 2015. 
inappropriate music content. There is a steady rise in the level and number of songs and accompanying videos, which promote nudity, coarse language, sexual stigmatization, perversion, lavishness, fraud, get-richquick approaches, violence, and gender discrimination. All of these are incompatible and constitute fundamental affronts to Nigerian laws. Thus, there has been a steady rise in the call for such songs to be properly evaluated before being allowed to be released to the public. Where a song fails to provide positive and meaningful content, it behoves on the various regulatory bodies, stakeholders and the society at large to censor such songs and reject such musical productions in order to ensure a sustainable development in the minds and character of the youths. ${ }^{5}$ While commending many music artistes who have helped shape the society in ways that have made the society better, politically, morally ${ }^{6}$ and economically, in recent times most of the trending musicians have increasingly generated music contents that are generally inappropriate and incompatible with legal, ethical, and normative requirements in Nigeria.

One principal reason for this trend is the proliferation and transplant of cultural norms and musical trends from foreign jurisdictions. These trends which could be considered appropriate in those jurisdictions, are generally not attuned or compatible with the diversified and more conservative nature of the Nigerian society. That boils down to the fact that many musicians of nowadays are trying to appeal to their greater audience made up of the youths. In doing so they give them what they want not what they need. Hence, musicians, in appealing to their audience would naturally sing songs that celebrate these wants of the youths instead of producing songs that instruct, educate, direct, mold, and correct the youths and give them what they need.

The aim of this article is to evaluate the legal and theoretical basis for regulating the contents of music and their videos in Nigeria. It goes further to provide a review of current Nigerian laws and how they are limited in addressing the problems of such negative contents. ${ }^{7}$ The article would

5 National Broadcasting Commission (NBC), various Media Houses, for example television and radio stations.

6 For example, songs like Message to the Youths by Evi Edna Ogoli, One Love by Onyeka Onwenu, Nigeria Unite by King Sunny Ade, Wait for Me by King Sunny Ade and Onyeka Onwenu, to mention just a few.

7 The National Broadcasting Commission (NBC), National Film and Video Censor Board (NFVCB) 
then present legal and theoretical proposal on how Nigerian laws and institutions could be better reformed to ensure appropriate content in music production and dissemination in Nigeria. ${ }^{8}$

This article is divided into five sections, this introduction being the first. Section 2 evaluates legal and theoretical basis for regulating music production in Nigeria. It uses interdisciplinary, socio-legal, theoretical, and doctrinal approaches to unpack the meaning and nature of what amounts to inappropriate content in music. Section 3 critically reviews the roles of statutory bodies established to ensure appropriate content in Nigeria. It highlights some of the weaknesses in those institutions that have exacerbated the dissemination of inappropriate music content in Nigeria. Section 4 contains legal proposals for reforming these regulatory institutions to make them more responsive and effective in enforcing appropriate music content in Nigeria. The paper concludes in section 5.

\section{LEGAL AND THEORETICAL BASIS FOR REGULATING MUSIC CONTENT}

Studies of popular music encompass a range of approaches from musicological, under which music is commonly analysed as a text, to sociological, which tends to focus on the social uses of popular music and the dynamic and interactive relationship between popular music, culture, and society, as well as law, which provides the legal basis from which a musician can air his opinion.

The new media and communications regulation needed to answer this research question is unavailable in Nigeria owing to the sudden increase in the music industry which needs more to be expected in areas of law to regulate and checkmate the trends it is towing. There are two "natural law" theories namely, theory of morality, or what is right and wrong, and theory of positive law, or what is legal and illegal. The two theories are independent of each other. Natural Law Theory of Morality states that people have purposes, and the "good" for any is the realization of its purpose. What is good for Nigerian youths is a flourishing life which involves the development and exercise of their capacities for rationality, abstract knowledge, deliberative choice, imagination, social cooperation based on a sense of justice, and so on. The moral virtues for

8 ibid. 
example temperance, decency, are character traits that help fulfil their true nature. Thus, the life of the violent, immoral or drug addict is not a good one, because it is inconsistent with the natural function of humans in general. Natural law is the set of truths about morality and justice; which principles are known even by means of unaided human reason. ${ }^{9}$ Immoral acts violate natural law and are "contrary to our function." 10

Legal systems have a function - to secure justice. Section 39(1) of the Nigerian Constitution provides that:

Every person shall be entitled to freedom of expression, including freedom to hold opinions and to receive and impart ideas and information without interference.

This fundamental right, which provides the platform, pursuant to which musicians produce their songs, is however regulated by other necessary and ancillary statutory provisions, principles of natural justice, equity and good conscience. Section 45 goes further to provide for the restriction of and derogation from such right by providing that:

(1) Nothing in sections ... 39... of this Constitution shall invalidate any law that is reasonably justifiable in a democratic society

(a) in the interest of defence, public safety, public order, public morality or public health; or

(b) for the purpose of protecting the rights and freedom of other persons. ${ }^{11}$

Hence, the law would not be broken if and when the content of music is fully regulated and analysed by the appropriate authorities. Although Lon Fuller ${ }^{12}$ has argued that there is a necessary overlap between legality and justice, ${ }^{13}$ it is impossible to have a legal system without fidelity to the rule of law and formal justice. The Nigerian society honours the principle

9 The natural law theory of morality rejects ethical subjectivism ("right and wrong are all a matter of opinion") and affirms ethical objectivism.

10 See J. M. Elegido, Jurisprudence, (Spectrum Law Series, Ibadan, 2004) 20-23. Thomas Aquinas holds, because the function of speech is to communicate to others what is in our minds. When we use words to mislead others, we are using them contrary to their proper function.

11 ibid (n 1).

12 Edwin W. Tucker, "The Morality of Law", by Lon L. Fuller University of Connecticut <www.repository.law.indiana.edu/ilj> accessed 30 July 2015.

13 ibid. 
of "no crime without a pre-existing, public law" hence, the question is who determines whether the lyrics and videos of Nigerian musicians have negative effects on the youth? And from what law can power be derived to censor or ban such intellectual property?

Ronald Dworkin postulates that it is proper for the courts to interpret the Constitution in light of the correct principles of justice that a country tries to honour. ${ }^{14}$ Legal Positivism states that a certain rule is a law, creating legal obligations to comply with it all depends on its source. According to HLA Hart, a contemporary legal positivist, the essence of legal positivism is the "separation thesis." 15 The separation thesis states that having a legal right to do $\mathrm{x}$ does not entail having a moral right to do it, and vice versa; having a legal obligation to do something does not entail having a moral right to do it, and vice versa; having a legal justification to do something does not entail having a moral justification, and vice versa; and so on. ${ }^{16}$ In order to know what legal rights are in regards to music content, the need to look at what appropriate content entails and the key provisions of laws in Nigeria that stipulate that music must be appropriate would be trite.

\subsection{Social Appropriateness}

The issue of ensuring appropriate content in music is critical to sustainable development in Nigeria. The more appropriate the lyrics of the songs are, the better will be the acceptance in a reasonable and orderly society, which the law aims at creating. Innovations and cultural transplant may be technically sound in the production of improved music, but may conflict with the social norms of the end consumers who are mostly impressionable youths. This societal disequilibrium can result in the total deviation from established customs and norms of the society as well as laid down laws put in place to ensure the sustainable development of the society. In some cases, the adoption of Western pattern of music videos

14 Dworkin, Ronald M., "Change in the Common Law: Legal and Economic Perspectives” (1980) Vol. 9, No. 2, The Journal of Legal Studies, 191-226. <http:/ /www.jstor.org/stable/724129> accessed 30 July 2015.

15 Kenneth Einar Himma, 'Legal Positivism of HLH Hart' (Seattle Pacific University: Internet Encyclopaedia of Philosophy) <www.iep.utm.edu/legalpos> accessed 30 July 2015.

16 Some of the most influential defenders of legal positivism are the 19th century philosophers John Austin and Jeremy Bentham, and the 20th century legal philosopher. 
and lyrics has resulted in a shift in the ideals within the Nigerian society. For example, the Nigerian society frowns at the indecent exposure of bodily parts by women - single or married. However, this has become the selling trend in most contemporary Nigerian music videos. This could cause a desensitization to what is permissible or not as to how a woman should appear in public based on various prevailing customary laws in Nigeria.

Hence, within the social context, there is also what can be termed situational appropriateness, that is, what is most likely to be accepted or rejected by relevant groups at any given time. ${ }^{17}$ For instance, at a time when the society is experiencing economic hardships, it would be inappropriate for musicians to produce videos that display their ostentatious lifestyles to the majority of those who cannot afford what they display. Also, in a case where most musical videos display nudity in the face of a growing depravity in the society, such proliferation of indecent and appropriate music would only fuel the increase of sexual related offences and ideologies.

\subsection{Economic Appropriateness}

The ability of musicians to incorporate appropriate content in their music has economic implications. The commercialization of inappropriate music results in musicians selling what the market demands and not what it needs. This act, for the most part, has negative effects on the society because it contaminates mind development and what constitutes social acceptance. This disrupts the legal framework already put in place to regulate music in Nigeria. Many musicians have stated that the production of certain types of music guarantees their financial returns while other kinds of music are economically unprofitable. Those that guarantee higher financial returns are often laced with inappropriate content as it obtains in many foreign jurisdictions.

Hence, the rationale for this is that a musician wanting to make money from his intellectual property would tilt to the production of songs that the market demands, be it appropriate or otherwise. Furthermore, many musicians who have inappropriate lyrics contend that such songs give them access to endorsements and acceptance by those establishments and

17 Relevant groups here include families, religious bodies, educational institutions, among others. 
companies that use them to reach majority of their target market. To these musicians, production of inappropriate music content is economically feasible within the present contemporary society.

While the musician seeks for his economic gain, the society suffers as such quest by the musician often has negative effects on the economy as a whole. For example, in a country where the average Nigerian lives on less than US\$1 a day, it would be an affront on the society for some musicians to flaunt extravagance in their videos in terms of money, houses, expensive drinks and the like. This portrayal of wealth often pushes fans to engage in criminal and desperate activities in order to make the kind of wealth displayed by their favourite musicians. This, in turn, affects the economy, as many people would not engage in meaningful hard work but illegal activities, which can lead to the injection of unregulated monies into the economy.

\subsection{Legal Appropriateness}

The overriding aim of law is to establish minimum standards and threshold to protect societal values and norms. Musicians and their producers might have constitutional rights and freedoms to sing, but such freedoms are not without legal and statutory restrictions. Legal appropriateness therefore, refers to the need to ensure that all forms of music produced in Nigeria comply with applicable laws and regulations that govern the music industry. If society cannot regulate the negative trends in music, the law must come in. All music produced must comply with applicable Nigerian laws and regulations. Nigerian laws and institutions that stipulate and apply minimum standards and threshold for music content would be considered as follows:

\subsection{A Regulatory Bodies for Music in Nigeria}

\subsubsection{The National Broadcasting Commission (NBC)}

This is a parastatal of the federal government, empowered to regulate the broadcasting industry. ${ }^{18}$ The vision of the Commission is to enable the emergence of a sustainable broadcasting industry that satisfies the social, political and economic needs of the people of Nigeria, the responsibilities

18 Act No. 38 of 1992 as amended by Act no. 55 of 1999. Now Cap N39 Laws of the Federation of Nigeria (LFN) 2004. 
of advising the federal government on the implementation of the national mass communication policy, with particular reference to broadcasting, as well as licensing cable and all terrestrial radio and television services. The Commission is also responsible for undertaking research and development in the broadcast industry, upholding the principles of equity and fairness in broadcasting and establishing and disseminating a national broadcasting code while also setting standards with regards to the contents and quality of materials broadcast. ${ }^{19}$ Also, the Act does not cover other sources of music which can be accessed by the youths in terms of internet or foreign outlets of such music. The role of the Commission here would be to strengthen human resource and institutional capacity for better service delivery while maintaining a policy of strategic engagement with stakeholders. $^{20}$

\subsubsection{The National Film and Video Censors Board (NFVCB)}

This body is governed by the National Film and Video and Censor Board $\mathrm{Act}^{21}$ which sets out a number of various infringements which include the distribution/exhibition of unapproved (uncensored/unclassified) films/video works and musical videos; forging the Board's certificates/ licences; distributing/exhibiting of pornographic films; broadcasting unapproved (uncensored/unclassified) films/video works by satellite/ cable television operators; exhibition of films with restricted classification to under-age persons; exhibition of films classified as "for restricted exhibition" in registered/licensed premises; failure of distributors/ exhibitors to distribute films in the film format for which they are intended (home entertainment format or public exhibition format). ${ }^{22}$

There are instances where one may want to circumvent the law by committing the offence after approval has been given for proper production. Hence, the Board has also provided a list of such acts, which results in an offence against the Act. These offences include altering already approved films/video works, posters and promos/trailers. The infringement of the Board's laws, most times, results in arrests and eventual

19 The Official Website of the National Broadcasting Commission <www.nbc.gov.ng/aboutus.php> accessed 22 July 2015.

20 In this case they would include the musicians, music label owners, music producers.

21 Cap N40 Laws of the Federation of Nigeria (LFN) 2004.

22 The official website of the Board <www.nfvcb.gov.ng/> accessed 15 July 2015. 
prosecution of offenders. However, some cases are settled out of court. Although the issue of infringement is discovered by monitoring which is the exercise that is carried out by the field officers of the Board to watch, keep track of or check the markets, video rental clubs and other places, to ensure that films/video works and their trailers that have already been approved have not been altered in any way.

Also, it ensures that distributors and distribution premises, exhibitors and exhibition premises are complying with the relevant laws. ${ }^{23}$ The Board also issues "Demand Compliance Notices" which are model notices sent to distributors and marketers of films/video works for contravening the Board's Act by releasing unclassified movies ${ }^{24}$ or airing unapproved promos. The Notices would indicate what sections of the NFVCB Act $2004^{25}$ that have been defaulted to the effect that defaulters would pay the specified amount as penalty and not only withdraw from circulation the offending movies but also publish a quarter-page notice of such withdrawal in two national dailies, as well as sponsor notice of withdrawals via national television and national radio service. These would be done within two weeks of receipt of the said Notice, failing which prosecution will be instituted against the defaulter.

The Act also enjoins a police officer or an officer of the Board who is authorized in that behalf to enter and search a premises and to ask for the name and address of any person within the premises who he reasonably believes to have committed an offence under the Act and to arrest such persons without warrant if he/she refuses to give an answer. Arrest could also be made in circumstances where a person is found in premises where incriminating materials are. Also in monitoring, if officers of the Board discover an outlet in use by an unlicensed distributor, unlicensed exhibition premises, unregistered retail outlet or unregistered rental outlet, they can seal up such premises to ensure compliance with the NFVCB Act and Regulations.

While all these methods to check what goes into the society by the Board are laudable, the effect has not been widespread as most of their actions are carried out with limited resources and half-hearted dedication

23 NFVCB Act 2004 and Regulations 2008.

24 By extension music videos.

$25 \mathrm{ibid}$ (n 21) as well as the requirements of the NFVCB Regulations 2008. 
and zeal. ${ }^{26}$ For administrative, enforcement and regulatory purposes, the Commission has its Headquarters in Abuja, with nine Zonal Offices and five Liaison Offices spread across the six geopolitical regions of Nigeria.

\subsubsection{Nigerian Copyrights Commission (NCC)}

The enacting Act of the Commission is the Copyright Act. ${ }^{27}$ They have the vision to harness the potentials of creativity for national development; as well as a mission to advance the growth of the creative industry in Nigeria through the dissemination of copyright knowledge, efficient administration and protection of rights. ${ }^{28}$ The Commission helps safeguard the intellectual property of musicians and their producers and ensures that credit is given to the right owners. In USA, an internet based

26 ibid (n 23). The official website of the Board provides a list of pending cases and cases that have been determined in different parts of the country. These pending cases include: NFVCB v Akinola Adegboyega - Court of Appeal, Ibadan; Adewale Joseph $v$ NFVCB - Federal High Court (FHC), Kaduna; Kingawa Ltd. v NFVCB E 2 Ors - FHC, Jos; Uchenna Nwachukwu \& 2 Ors v NFVCB - FHC, Awka; Onyeka Orajiaka E 12 Ors v NFVCB E Anor-FHC, Awka; Hon. Olatunbosun Kazeem $v$ Lagos State Film Committee \& Anor - Lagos State High Court; Incorporated Trustees of Motion Practitioners Association of Nigeria $v$ Kano State Censorship Board E 3 Ors - FHC, Kano; Chibuzor Obiajunwav Chief Sunny Collins Nwatu E NFVCB - FHC Awka; Chibuzor Obiajunwa v Austin Okafor E NFVCB - FHC, Awka; Terry Ngene Okoro v Samson Kaliwa-CMC, Yola; NFVCB Vs Terry Ngene Okoro - CMC, Yola; COP v Titilayo Segun - MC III, Suleja; COP v Kazeem Ijiwande - Oshogbo. Cases determined between 2003 2011 include: Abodunrin Olanrewaju v NFVCB - FHC, Ibadan; Akachukwu Ibe v Emeka Mba \& 5 Ors - FHC, Awka; Ogbonnaya Progress \& 9 Ors v NFVCB E 4 Ors - FHC, Benin; Helen Ukpabio \& 1 Other $v$ NFVCB; COP v Ugonma Okafor E Ors (2003); COP v Nura Adewale E Ors (2003); COP v Uche Andy $\mathcal{E}$ Ors (2006); NFVCB v Vee-Cee Video Centre, Samalin VC and Lucky Star VC (2006); COP v Ikechukwu Ogugua (2004); COP v Ugonma Charles (2004); COP v Osita Onwumelu E Anor. (2006); COP v Onyebuchi Nwobu (2005); COPv Okechukwn Okoye \& 5 Ors; COPv Helen Ukpabio; Adegboyega Kolade $\checkmark$ NFVCB; COP v Ekene Oranyelu (2006); Balogun Martins Ajab E Ors v NFVCB (2006); VCOAN E Adebusuyi Moses v NFVCB(2006); Registered Trustees of VCOAN v NFVCB; Chiddo Productions and Global Ltd \& 12 Ors v NFVCB; COP v Jude Ikwuakaam \& 13 Ors; COP v Oludare Atere \& Anor; NFVCB v Mrs. Bola Jatto; Kingsley Ogoro v NFVCB; NFVCB v JACOFIC (Babajide Kosoko); Abiodun Seun v Basil Ugbede - all unreported.

27 Cap C28 Laws of the Federation of Nigeria, 2004.

28 The home page of the Copyrights' Commission provides these and more information about the workings of the Commission < www.crc.gov.ng $>$ accessed 25 July 2015. 
company, Napster, created by Shawn Fanning, which was a music web site that allowed people to download music at any time was shut down because it infringed on the copyright of various musicians, whose music was given free access via the website without authority. The Recording Industry Association of America (RIAA) provided a list of all the copyrighted music and filtering was done on Napster. In Nigeria, like many countries, there is no law sufficiently governing copyrighted music, especially as it concerns the Internet.

Recent findings show that about 48 per cent of people in the USA do not even purchase Compact Discs (CDs) anymore because they can download the music for free on the Internet. Unknowingly, people, especially pirates who download for commercialpurpose, download music to $\mathrm{CD}$ and other transmittable devices to access various trending musicals. The NCC can deem this illegal, for the primary concern of copywriting people, is the loss of revenue from selling music in the music shops and other outlets. Hence, while the NBC and NFVCB deal with the content and output of the music, the NCC is concerned with the copyright regulation and safeguard of financial gain for the musicians and producers. Hence, NCC does not bother with lyrics or video materials.

\subsubsection{Limitations of the Legal Framework in Addressing the Negative Contents in Music}

On the horizon, of the contemporary music industry is a new generation of Internet record labels, distribution of digital music from the musicians directly to the consumers, and an increase in private recording companies and media houses. Digital music is electronic bits of information distributed through Internet networks, telephone lines, cable systems, and satellite transmission. Over the past decade, Internet file sharing has become the way to get the music any youth would like the most. Unfortunately, the various relevant bodies are not up to date with modern technological advancements in the music industry. This has contributed to the increase in the proliferation of negative-themed music lyrics and videos, which get to the targeted audience - the youths - faster than even the regulatory bodies can screen.

Also, Nigeria lacks the needed technology to curtail Internet access like in many developed countries where Internet providers are regulated by the relevant government agencies to safeguard what the society can access via the web. Therefore, while the NFVCB can intercept any illegal material from warehouses and open markets, the Internet space is thriving and being used to channel such illegal, unapproved and negative music. 


\section{EVALUATION OF CURRENT MUSICAL PRACTICES AND THE INFLUENCE ON YOUTHS}

Music is highly influential and has the capacity to create both positive and negative impacts on youths in any society. The age of youths is a period where opinions are formed and values are established. It is also a period where young children transcend into adulthood. Where the values and morals of such youths are not properly formed, the future of the society would arguably be jeopardized. Conversely, music can also play a vital role is moulding the tenets of the society, especially on impressionable youths who are leaders of the future. ${ }^{29}$ There is the need to also consider the appropriateness of lyrics and videos of the music; more so that the video concept usually adds content to the lyrics and provide a particular interpretation that is reinforced every time the viewer hears the song. The perception and the effect of music-video messages on youths are related to the developmental and emotional stage of the viewer, as well as their level of exposure.

In 2003, a report from the USA by the Kaiser Family Foundation ${ }^{30}$ revealed that three of four of those in the 16 to 24-year-old group watch MTV a music satellite station, whereas 58 per cent watch it at least once a week, and 20 per cent watch it for an hour or more every day. More recently, a study revealed that a sample of 12 to 15 -year-olds watched music videos on an average of 4.3 days per week. ${ }^{31}$ With such statistics, it is obvious that the media inclusive of music has a big role to play in the influence of youths.

Listening to music over time causes the lyrics to be engrained into the lives of the youths. Also, watching the videos of such music can leave an indelible mark in the memory of the youth who views such constantly. Thus, listening and watching such music contribute to the shaping of the mindset and values of such youths. Music has been a way of expressing feelings and thoughts which the youth may be expressing, thus providing

29 See also Kubey R, Larson R, “The use and experience of the new video media among children and young adolescents" (Communication Resources, 1990; 17 (1):107-130). Retrieved from <www.pediatrics.org/> accessed 30 July 2015.

30 Henry J. Kaiser Family Foundation. Reaching the MTV generation: recent research on the impact of the Kaiser Foundation/MTV public education campaign on sexual health <www.kff.org/entmedia/Reaching-the-MTV-GenerationReport.cfm.> accessed 28 July 2015.

31 ibid. 
an outlet for him or her. Music helps relieve the stress of daily life even for the youth who may still be in school or in early stages of employment. Music can be termed negative when it is lacking in constructiveness, helpfulness, optimism, cooperativeness, or the like. ${ }^{32}$

Musical lyrics have become increasingly explicit over the decades. Songs make common graphic references to sex, drugs and violence, unlike the past where sensitive issues were cleverly veiled. However, disturbing lyrics and the amount of violence portrayed in some trending music are becoming a great concern to many adults. Analysis of the content in music videos is important, because research has reported that exposure to violence, sexual messages, sexual stereotypes, and use of substances of abuse in music videos might produce significant changes in behaviours and attitudes of youths. ${ }^{33}$ A survey performed among 214 adolescents revealed that there was an association between music video watching and permissive sexual behaviours. ${ }^{34}$

Arguably a large percentage of music videos by Nigerian artistes have similar content, which often feature scantily dressed women, affluence of money, ostentatious goods, and the ratification of the excess consumption of alcohol. In a recent issue between the videos of one of such Nigerian music artistes, ${ }^{35}$ it was stated by a section of the interested public that the video further pushed the boundary of decency and what should be publicly acceptable by the public media. One of the analysts ${ }^{36}$

32 Merriam-Webster Dictionary also defines negative as harmful or bad; not wanted; thinking about the bad qualities of someone or something: thinking that a bad result will happen: not hopeful or optimistic; expressing dislike or disapproval; marked by features of hostility, withdrawal, or pessimism that hinder or oppose constructive treatment or development $<$ www.merriam-webster.com/dictionary/ negative $>$ accessed 23 July 2015.

33 Amy Morin, “Can Music Be a Bad Influence on Kids \& Teens?” (27 January 2015) <www.livestrong.com/ 2015/01/> accessed 28 June 2015.

34 Roberts DF, Henriksen L, Christenson PG. Substance Use in Popular Movies and Music, Washington, DC: National Youth Anti-Drug Media Campaign, Office of National Drug Control Policy, and Department of Health and Human Services, Substance Abuse and Mental Health Services Administration; 1999. Retrieved from American <http://www.academyofpediatrics.com> accessed 30 July 2015.

35 David Adeleke with the stage name of Davido's music video titled, 'Fans Mi' featuring American rapper, Meek Mill.

36 Tofarati Ige, Why Your Children Should Avoid Davido's Video "Fans Mi" Vanguard (Nigerian Newspaper, June 2015) <www.vanguardngr.com/2015/06/ why-your-children-should-avoid-davidos-video-fans-mi/> accessed 28 June 2015. 
of the said song exhibited the wide display of several types of guns and money. This was also accompanied with scenes and repeated shots of scantily dressed girls in the guise of the musician portraying a business deal with another to supply substance, which could be assumed to be sensitive, dangerous and unlawful. This assumption can be reached by the inference of the presence of weapons and large amount of money, which was displayed. It is not until the end of the video that the musician reveals the substance he purchased earlier to be a Nigerian food. ${ }^{37}$

Furthermore, drug and alcohol use is often glamorized in most trending Nigerian music lyrics and videos. Musicians often portray substance use as trendy without showing the negative consequences of addiction..$^{38}$ Basically, the questions to those in charge of producing music and regulating what is allowed for public consumption are: what is to be taught and benefitted? Is the use ofguns permissible? Is it okay to engage in the sale of illicit drugs to make money? The answers herein must be considered and weighed on the imaginary scale of those concerned. These questions are important and their answers imperative, as the majority of music aired for the public through various media is largely targeted at many impressionable youths?

\subsection{Influence of Foreign Culture and Norms}

There is no gainsaying that many of the contemporary Nigerian music, patronized by many youths are fashioned after those from the USA music trends, especially from the rap/hip-hop genre. USA is a country where a diverse genre of music exists. Notably, popular among their youths are rock music and hip-hop or rap. Over the past four decades, lyrics in rock music have undergone dramatic changes. It is more explicit with reference to drugs, violence and sex. Studies show that preference for heavy metal music may be a significant indicator for alienation, substance abuse, psychiatric disorders, suicide risks, sex-role stereotyping, or risk taking behaviours during adolescence. ${ }^{39}$ The current preoccupations of rap music,

37 ibid.

38 ibid (n 38).

39 Federal Trade Commission, Marketing Violent Entertainment to Children: A Review of Self-regulation and Industry Practices in the Motion Picture, Music Recording, and Electronic Games Industries (Report of the Federal Trade Commission, Washington, DC, 2000). Federal Trade Commission, Follow-up Report on Marketing of Violent Entertainment to Children (Washington, DC, 2001). <www.pediatrics.org> accessed 30 July 2015. 
especially the erotic themes expressed and their dramatization in music videos, have led to an adverse youthful acceptance of profanity, vulgarity, sexual abuse, and violence. Hence, many parents in USA think that rap music is just a glorification of violence. Forty-seven per cent of mothers with children in public schools believe that violent messages in rap and rock music contribute a great deal to the negative trends among their children and wards.

Many heavy metal and hip hop ${ }^{40}$ musicians sing perversions and push negative values upon the youths in the USA with little resistance from the society. ${ }^{41}$ The end result is disaster and many youths suffer from the influence of such musicians. ${ }^{42}$ The negative trends in most music preferred by the youths in USA have caused them to see what ought to be acceptable or fashionable to our society as being archaic and has caused promiscuity, gun violence, marijuana and other illegal substances to become acceptable among them. This trend goes against the fact that the society we live in promotes the development of educated, healthy, properly dressed, morally upright, well-mannered men and women.

Among efforts to check the negative lyrics and videos among youths in the US, there now exist many groups and movements formed to advocate against the trendiness of such music. There is the nongovernmental organization known as the Parents' Music Resource Centre (PMRC), which is trying to censor and outlaw the contemporary music in USA. A mother and investigative reporter for a newspaper in the small town of Merced, California, Layla McLean, displayed contempt towards the contemporary music trending today, stating that within the last three

40 Wingood, G.M., DiClemente, R.J., Bernhart, J.M., Harrington, K., Davies, S.L., Hook, E.W. III, A prospective study of exposure to rap music videos and African American female adolescents' bealth (Am J Public Health, 2003, 93 (3):437-439) <www. www.pediatrics.org> accessed 30 July 2015. Took KJ, Weiss DS, The relationship between heavy metal and rap music and adolescent turmoil: real or artefact? (Adolescence.1994;29 (115):613-621) Retrieved from <www. www.pediatrics.org> accessed 30 July 2015.

41 Rustad, R.A., Small, J.E., Jobes, D.A., Safer, M.A., Peterson, R.J., The impact of rock videos and music with suicidal content on thoughts and attitudes about suicide (Suicide Life Threat Behaviour, 2003, 33 (2):120-131). Retrieved from <www. www.pediatrics.org > accessed 30 July 2015.

42 This is because the youths of the early 80's to the 90's who were so adversely affected and influenced by the negative lyrics and videos of such songs became the parents of the present generation, often as a result of teenage pregnancies, rape and distorted values, and passed on same to their offspring. 
years she had done multiple reports around the music that had been found playing after a teenager who committed suicide was found. ${ }^{43}$ She stated that "listening to half of the music most kids listen to on a daily basis would be enough to ruin a day, not to mention glorify[ing] suicide and influence self-harm." Currently, in the USA, youths can access music easier and quicker through streaming programmes from the Internet. This means that many musicians in the music industry can show the world their music. Possibly the most used format of accessing music would be from the American online company called YouTube, where music videos are freely accessed and downloaded without restriction.

In the final analysis, music has for a long time had negative influence on the American society, most especially its youth. The major genres, rock/heavy metal and rap/hip-hop have been shown to cause many youths to rebel against basic laws and truths that govern the society as a whole. Hip-hop began to change the very appearance of its followers by creating a look, a way of governing oneself, and a language that should be spoken. What this created was a subculture of the American culture, and it caused their youths to go against the basic pattern of society and manifest their own will regardless of what it cost them socially and morally.

\section{NEGATIVE AND INAPPROPRIATE TRENDS AND EFFECTS}

Although the laws establishing the relevant regulatory bodies do not categorically list out what is or is not negative, these bodies have the discretion and authority to declare a musical production negative and consequently banned. The Black's Law Dictionary ${ }^{44}$ defines negative as, “... relating to something bad; not positive." The trend in most music lyrics and videos, which appeal to the youths in contemporary Nigeria are often laced with negativity and messages that do not support or contribute to sustainable development in the country. As with trending music, the perception and the effect of music lyrics and video messages

43 Samantha, “The Effects of Negative Music on Today's Youth" (Monthly Edition,12 July, 2011). Retrieved from <www.googlesearch.com//> accessed 19 July 2015.

44 Black's Law Dictionary, 9th Edition. 
are important, because research ${ }^{45}$ has reported that exposure to violence, sexual messages, sexual stereotypes, and use of substances of abuse in music videos might produce significant changes in behaviours and attitudes of the youths.

There is the constant exposure to negative issues such as sex, drugs and violence, and their celebration thereof, which can lead to undesirable behaviours. Such behaviours can cause increase in children born outside wedlock among teenagers and young adults, and the misuse and abuse of drugs as a result of imitating the musicians who flaunt these in their videos. Finally, there could be resort to violence as a way of channelling grievances, settling disputes and expressing opinions.

Most song lyrics do not discuss dangers of sexual activity, such as unplanned pregnancy or sexually transmitted diseases. Instead, they often glorify promiscuity and promote gender stereotypes. The negative connotation associated with trending Nigerian music can be greatly attributed to the elements of sex, gambling, and drinking excessive amounts of alcohol, which are commonly associated with music videos youths are exposed to. Lewd, which can be said to mean crude and offensive in a sexual way, is gradually becoming the norm in contemporary Nigerian music, popular among the youths.

Many musicians do not serve as positive role models for the youths that listen to their music. Some of these musicians are youths themselves; some have dropped out of school to pursue their music career, the quest for money and fame. This may translate to increase in the decline of educational pursuit by many youngsters. Also, many musicians have personal lifestyles ${ }^{46}$ not worthy of emulation by the youths who look up to them for inspiration and direction in their lyrics and videos. Relevant

45 Reddick $\mathrm{BH}$, Beresin EV, "Rebellious rhapsody: metal, rap, community and individuation” (Academic Psychiatry.2002;26 (1):51- 59); Martino SC, Collins RL, Elliot MN, Stratchman A, Kanouse DE, Berry SH. 'Exposure to degrading versus nondegrading music lyrics and sexual bebaviour among youth.' (Pediatrics.2006;118 (2).) <www.pediatrics.org/cgi/content/full/118/2/e430>; Knobloch-Westerwick S, Musto P, Shaw K. "Rebellion in the top music charts: defiant messages in rap/hip hop and rock music" (1993-2003). (International Communication Association Conference; Dresden, Germany, June 19-23, 2006).

46 Many have children out of wedlock; many have been jailed; many have been pictured using hard drugs and engaged in drunkenness; many have pierced their bodies with rings and tattooed themselves for fashion; many have displayed wastage of money in the amount spent on cars, houses, clothing and parties. 
and recent examples include the song 69 Missed Calls by Nigerian artistes, Jahbless, Olamide, Reminisce, Lil Kesh, CDQ, Chinko Ekun, and another song titled Tesojue by Reminisce. ${ }^{47}$ Not only do both songs contain lewd and explicit contents about nocturnal sexual activities, they arguably promote the glorification of women as sex slaves. Their lyrics and video contents provide disturbing images of promiscuity, sexual deprivation and negative exuberance.

These and other similar videos highlight the fierce urgency in which the contents of music videos and music lyrics need to be addressed to curb negative effects on the youths in particular, and the society in general. It would be a tragedy if this generation is remembered for the decay in music as a representation of the moral decline and the representation of the inappropriate ideal of the youth. Unfortunately, mere shielding of youths from negative trending music is not the answer to preventing youth for it only adds to the problem of forcing them to shatter their parents and guardians' rule and protective nature. Also placing a legal ban on certain music may result in the violation of the musicians' fundamental right to freedom of speech. Many would suggest that censorship should be employed in curtailing negative trends in contemporary music because lyrics from such tell youths that it is acceptable to participate in illegal and negative actions. An understanding of contemporary music is what is needed, and what music means to the musicians who make them, then the re-direction of these talents for more sustainable development ideas.

\section{ROLES OF STAKEHOLDERS}

There is the severe exigency for which the issue of the content of the music videos and music lyrics need to be addressed to curb negative effects on the youths in particular and the society in general. To achieve this, all key stakeholders and players in the music industry have fundamental responsibilities and roles in fostering appropriate music content in Nigeria.

47 Reminisce, 'Tesojue [Explicit Video]', available at <https://www.youtube.com/ watch?v=Ep879pz-TAo $>$ accessed September 25, 2015; also Jahbless ft. Olamide, Reminisce, Lil kesh, CDQ, Chinko Ekun , '69 Missed Calls' <https:// www.youtube.com/watch?v=3B6OkCW73J4> accessed September 25, 2015. 


\subsection{The Musicians and Music Producers}

The music industry is made up of the musicians, their producers, and interest groups, among others. These musicians belong to various interest groups such as the Performing Musicians Association of Nigeria (PMAN), which serves to protect their interests as well as provide internal regulations of the industry. The music industry may argue that it has fulfilled its part in advising youths to what the lyrics content in the music entails with the use of parental advisory stickers. However, Nigeria has not developed to the stage where youths are denied the sale of such restricted music based on their ages. There is no way to determine if the purchaser of a song is mature enough to so do. The time is ripe when the music artistes culpable for such wide spread degradation of the society based on the negative content of their music should be made responsible for the consequences in the society. The artist controls the factor of how they express their thoughts and feelings within their lyrics.

The music industry has majorly failed to produce videos with more positive themes about relationships, ethnical harmony, drug avoidance, nonviolent conflict resolution, sexual abstinence, pregnancy prevention, and avoidance of promiscuity as a whole. Music sells; but at whose cost? This question is pertinent in determining what would be the driving force of the music industry. If negativity sells, would that become mass production for the public at the expense of the youth's growth and sustainable development? These questions have answers, which lie in the domain of the musicians and the music industry as a whole.

\subsection{The Media Houses}

These include television and radio stations licensed to operate in Nigeria. While government's regulatory bodies do their part in checking what is produced and permitted for sale to the public, the various media houses have their role of enforcing such decisions of the regulatory bodies. Unfortunately, if NBC's actions were to ban certain negative songs, such ban will only affect the "free to air" TV stations such as the Nigerian Television Authority (NTA), Silverbird Television (STV), African Independent Television (AIT) and others. A lot of Nigerians get their trending music from satellite TV platforms like Sound City, Channel O, Nigezie, MTV base and sometimes Trace Urban, while many more go to YouTube. These satellite TV stations are not obliged to enforce any NBC's sanctions since their platforms are not "free to air" but "pay TV channels".

In 2009, the NBC banned certain Nigerian musicals for exhibiting 
vulgarity and indecency. ${ }^{48}$ Additionally, AIT banned a Nigerian musician Bigiano's song titled Shayo from being played on its airwaves. In 2011, 2Shotz's "Super Man Dead" was banned by the NBC for the use of the word "Alomo". Again, in 2013, NBC ${ }^{49}$ issued a list of music videos ${ }^{50}$ that they tagged "Not to Be Broadcast" (NTBB) and the reasons why they were banned. In 2014, NBC partially banned Lil Kesh's Shoki remix featuring Olamide and Davido a then trending music among Nigerian youths. ${ }^{51}$ This partial ban meant that the song would still be aired but only at seemingly odd hours. ${ }^{52}$ While some musicians get total ban, others get partial ban and others get fined.

Also the NBC fines erring media houses along with those musicians who flaunt their regulations. The most recent action taken by the NBC to again ban certain songs by labelling them, "Not to be broadcast" (NTBB) was borne out of the fact that they contained obscene video,

48 Enter the place by 2 face Idibia, Dance for me by Duncan Mighty, Suddenly and I wanna be close to you by D'banj, Nwa Baby and Rigirigi by Flavour, and Maga Don Pay by Kelly Handsome. "Banned Musicals" < www.vanguardngr. com/ content/view/34334/81/> accessed 28 July 2015.

49 January 2013 NBC issued a list of banned videos including Wizkid's "Caro", Olamide's "Silly Love”, Phyno’s “Ghost Mode”, "Gobe” by Davido, "Voice of the Street" by Olamide and many more.

50 Tillaman $\mathrm{ft}$ Vector - Ma Roll (contains Intimate and suggestive dance steps); Wande Coal - Go Low (scenes of nuditiy in the video); D’Prince - Take Banana (contains Intimate, vulgar, words and suggestive dance steps); Flavour - Shake (vulgar and suggestive dance steps); Goldie - Ski bo bo (features minor with suggestive and immoral dance steps); Chuddy K - Chop My Dollar (features ladies and children with suggestive and Intimate dance steps); Timaya - Shake Ur Bum Bum (Intimate, suggestive dance steps with vulgar lyrics; P Square Alingo (Intimate dance scenes at the end of the musical video).

51 <http://.net/2014/09/19/why-we-banned-shoki-nbc-reveals-must-read/> accessed 30 July 2015.

52 Partial ban restricts airing of the particular music between $10 \mathrm{pm}-5 \mathrm{am}$ 
drug trafficking, vulgar lyrics and violence, among others. ${ }^{53}$ Interestingly, some foreign music and videos were added to the list and classification of ban into audio ban or video ban or both were indicated for each that was banned.

However, many have argued that such songs ought to have been banned before the songs enjoyed airplay in the first place. Since the regulatory bodies have performed their roles mostly in the reactive rather than the proactive, they must be held responsible and made to do a better job of regulating these songs before they turn viral on Internet and media houses and stations. It is expected that the regulatory bodies should issue a comprehensive guideline to all Nigerian music practitioners to put an end to uncoordinated, selective and unproductive banning of negative music videos.

\subsection{Government}

The government, through its relevant agencies and bodies, has a role to safeguard the morality and laws of the society. The government does this through its various agencies, many of which are regulatory. These include NBC, NFVCB and the Nigerian Copyrights Commission, among others. The reactive rather than the proactive attitude of these bodies is the cause of the fast growth of indecency, violence and acceptance of drug abuse among other vices and negative trends in the music. This is worrisome owing to the fact that the Nigerian culture, morals and values will soon take the backseat to the negative Western-influence. Although these bodies are limited in their control over the Internet, market, satellite stations

53 “Yayo” by Phyno for its obscene video; “Tesojue” by Reminisce for vulgar lyrics; "Anaconda" by Nicki Minaj for vulgar lyrics and obscene video; "Indomie" by Olamide for obscene video; “Tony Montana” by Naeto C. featuring D’Banj for violent depiction in the video; "Gbesere" by Lil Kesh for vulgar lyrics; "Ibadi" by May D for obscene video; "Fans Mi” by Davido for video promotion of ostentatious lifestyle, violence, drug trafficking and indecent exposure; "Post to be" by Omarion featuring Chris Brown and Jhene Aiko. The list was pasted on the wall within the premises of NBC titled NOT TO BE BROADCAST (NTBB) LIST OF JULY 2015 and was cited by a social media blog: <www.lailasblog.com/ 2015/08/check-out-new-list-of-songs-banned-by.html?m=1> accessed 12 August 2015. See also DuRant RH, Rome ES, Rich M, Allred E, Emans SJ, Woods ER "Tobacco and alcohol use behaviours portrayed in music videos: a content analysis" (Am J Public Health.1997;87 (7):1131-1135); see also Robinson TN, Chen HL, Killen JD. "Television and music video exposure and risk of adolescent alcohol use. Paediatrics” (1998;102 (5)) <www.pediatrics.org/cgi/content/full/102/5/e54> accessed 1 July 2015 
and other alternative veritable sources of music and their videos, they can, to some extent, send a message to artists and producers bordering on the content of their music. This message can be in form of warning, partial banning, complete banning, restriction of airing and payment of fines for any law contravened.

It is arguable that while certain government agencies are mainly responsible for music, other agencies can also play relevant roles in criticizing the music content of some Nigerian songs. In a report recently published in the Nigerian Punch newspaper, the Director of Public Affairs of the NDLEA, Mitchell Ofoyeju, was quoted as saying that the agency had set up a panel to investigate the making of the video, which he alleged had clearly promoted drug trafficking. ${ }^{54}$ While reacting to the issue of the song by Davido "Fans Mi", Ofoyeju said he had watched the video and noticed it was not okay for public viewing. ${ }^{55} \mathrm{He}$ went further to state that:

The video has no positive impact on the society, no ethical message either; instead, it is evidently against what we confess. I have to this effect set up a panel to checkmate him, his video, why he would go ahead with such a video where he was seen exchanging a briefcase purportedly containing sedatives for dollars, exhibiting affluence which is questionable, probably based on drug trafficking or something I can't conclude on for now. ${ }^{56}$

This statement cannot be brushed aside as a personal opinion as Ogoyeju by virtue of his office speaks for a Nigerian federal government agency. Consequently, following the decision of the NDLEA to investigate if the controversial video of Davido's recent duet with American rapper, Meek Mill, titled "Fans Mi", was censored, the Acting Head, Corporate Affairs of the Nigerian Film and Video Censors Board, Mike Ekunno, said that it did not approve the video before it was released..$^{57}$ But the grey area remains that it is hard to determine whose responsibility it is to approve music videos shot by Nigerian artistes, whether the NBC or the NFVCB.

54 < http://dailypost.ng/2015/07/15/fams-mi-davido-risks-15-years-imprisonmentn2m-fine-for-promoting-drug-trafficking/> accessed 23 July 2015.

55 ibid.

56 ibid.

57 ibid. 


\subsection{Parents and Guardians}

Many parents often are unaware of the lyrics which their children are listening to because of the increasing access to it through the use of downloaded music and headphones. They have the duty to ensure that music videos and music lyrics marked with "parental advisory" warnings are adhered to by those who are caught in such age brackets. In a nutshell, parents must educate and convince them on why such preference goes against the tenets of morality, common sense, general Nigerian culture and any relevant law in force in Nigeria. ${ }^{58}$ The Child Rights' Act ${ }^{59}$ provides that:

Every parent, guardian, institution, person and authority responsible for the care, maintenance, upbringing, education, training, socialization, employment and rehabilitation of a child has the duty to provide the necessary guidance, discipline, education and training for the child in his or its care such as will equip the child to secure his assimilation, appreciation and observance of the responsibilities set out in this Part of the Act. ${ }^{60}$

The Act goes ahead to provide for various protections of the rights of a child. ${ }^{61}$ Hence, both the law and the society lay a great expectation on the parents and guardians of children and wards to raise up people who would be able to decipher what is positive and negative, and choose the positive. Hence, parents and guardians must take a more active role in monitoring their children's listening habits and choice of music.

\subsection{Religious Bodies}

Most contemporary secular musicians started their music careers in the church as choir members or sole singers. ${ }^{62}$ Although these musicians are

58 For example, it will be in the best interest of the child or ward of a parent or guardian not to engage in music that promote same-sex sexual relationships as it goes against the Prohibition of Same-Sex Marriage Act, 2014 of Nigeria. Also, a child that adheres to music about the appropriateness of banned drugs, narcotics or alcohol for adults would be liable to be exposed to the NDLEA laws. Also any children whose choice of music artistes promotes sexually illicit scenes in his music video and music lyrics be at risk of the law if he goes ahead to carry out such acts with another.

59 2003, cap. C50 Laws of the Federation 2004.

60 qSection 20.

61 Sections 21-34.

62 For example, in Nigeria, the likes of Terry G, Wizkid, D’Banj. 
not clergy, they have huge moral responsibilities to the people. It is arguable that not much advocacy has been done by the various religious bodies in Nigeria to kick against the negative trend in music. Many religious bodies adapt the dance steps and rhythm of such negative music in their religious practices among their congregation. The Holy Bible states that, "Evil communication corrupts good manners". ${ }^{63}$ These communication includes the lyrics of music listened to by their members. When the youths are allowed to listen to inappropriate lyrics of indecent, violent and vulgar music accompanied with similar kinds of video they would grow insensitive to what is right and wrong and soon consider what is negative as acceptable. Hence, there is the fierce need for religious bodies to steer their members, especially the youths in the right way in the area of music.

\subsection{Corporate Entities}

One means by which a musician can attain popularity faster than peers is through endorsement; which is determined by their ability to magnetize fans and command good appearance fee. From mobile telecommunication companies to international electronic companies and even the government and its parastatals ${ }^{64}$ every trending music or musician is often deployed to carry out a message to the public, especially the youths. Today, more than half of corporate employers now use social media to screen applications for employment. This move can also be extended to the selection process by corporate bodies and sponsors, in determining whom they endorse as brand managers and ambassadors. ${ }^{65}$ Those indiscretions contained in their videos and lyrics which often showcase drunken parties, insensitive jokes, negative tribal comments, negatively extreme political expressions, religious fanaticism, offensive language, bad reports/ comments of the musician by others about his profile among others, should provide a doubt on such musician's suitability for roles by the corporate bodies and sponsors. ${ }^{66}$

In engaging those whose lyrics and videos depict negativity, the public, especially the impressionable youths would be convinced that negativity

631 Corinthians 15:33 of the King James Version.

64 <www.wealthresult.com/2015/02/top-20-richest-musicians-in-nigeria-and.html>

65 David Adeleke also known as Davido is a brand ambassador for MTN a Multinational Telecommunications Company.

66 A recent study on how a potential employer uses social media in the hiring process. 
sells. The various commercial industries often use effective advertisements that attract youth with glamorous, pleasurable images and sounds that stir them into negativity and desperation. It would hardly be arguable to state that if majority of the corporate bodies and sponsors who employ the services, publicity and popularity base of these musicians, decline to endorse those culpable for negative music videos and lyrics, the trend would change.

\subsection{The Youths}

If one chooses to make negative music, the youths have a choice to listen to it, or not. However, not many youths are able to make proper choices, and need direction and guidance. Where such is lacking or has been given, the onus now lies on the youths to decide what kind of music and its message they would choose to listen to and follow. The Child Rights' $\mathrm{Act}^{67}$ provides that:

(1) Every child has responsibilities towards his family and society, the Federal Republic of Nigeria and other legally recognized communities, nationally and internationally.

(2) It is the duty of a child, subject to his age and ability and such other limitations as may be contained in this Act and any other law, to-

(b) respect his parents, superiors and elders at all times and assist them in case of need;

(c) serve the Federal Republic of Nigeria by placing his physical and intellectual abilities at her service;

(d) contribute to the moral well-being of the society. ${ }^{68}$

This provision of the law reiterates the role the youths have for themselves in order to preserve the moral standard of the Nigerian society by respecting the opinions and counsel of his parents and guardians. Hence, young people have the personal responsibility to become more selective and critical of today's music in order to decide if such trending music being produced contributes to a sustainable development of the society they will lead in the near future. ${ }^{69}$

67 2003, cap C50 Laws of the Federation 2004.

68 Section 19.

69 L'Engle KL, Brown JD, Kenneavy K. The mass media are an important context for adolescents' sexual behaviour. J (Adolescent Health.2006;38 (3):186-192) <www.pediatrics.org/cgi/> accessed 11 July 2015. 


\section{RECOMMENDATIONS}

The way in which society influences the individual is vital in explaining prevalent behaviour. Therefore, the remedy involves identifying the influential social factors and introducing change to alleviate their impact on the individual. This paper has identified music as one example of a societal influencer by criticizing its negative effects on youths based on inappropriate content. Hence, the need for a way out is apposite if sustainable development is to be guaranteed among the youths' perception to life via music. ${ }^{70}$ Whether it is music we play by personal choice or music we hear in supermarkets or a retail store, society will hear music. What comes along with the music and markets the music is what will affect the listener and invariably the society. These recommendations cut across those who may be held responsible for the influence of music in the society. ${ }^{71}$

Firstly, the various regulatory bodies should be proactive and not reactive. Steps must be taken to review and preview music lyrics and videos before they are approved to be released into the public either through media houses or for Internet streaming. The regulatory bodies in charge must perform a content analysis of music revealed that what is produced has content appropriate to their target audience. ${ }^{72}$

Similarly, censorship should be carried out against any erring music and video irrespective on the financial implication on the musician and producer. Music censorship is an act that advocates or allows suppression, control, or banning of music or music related works against the wishes of its creator or intended audience. This is done in Nigeria by the NBC and NFVCB. ${ }^{73}$ Some members of the society and the music industry have

70 See also Chapin JR. Adolescent sex and mass media: a developmental approach. Adolescence.2000;35 (140):799- 811 retrieved from < www.pediatrics.org/> accessed 1 July 2015.

71 See also Henry J. Kaiser Family Foundation. Parents, Children E Media: A Kaiser Family Foundation Survey. Menlo Park, CA: Henry J. (Kaiser Family Foundation; 2007) Retrieved from <www.kff.org/entmedia/upload/7638.pdf.> accessed 22 July 2015.

72 See also Anderson CA, Carnagey NL, Eubanks J, 'Exposure to violent media: the effects of songs with violent lyrics in aggressive thoughts and feelings' J Pers Soc Psychol (2003;84 (5):960- 971) retrieved from <www.pediatrics.org/> accessed 1 July 2015.

73 See also Gentile DA. Teen-Oriented Radio and CD Sexual Content Analysis. Minneapolis, MN: National Institute of Media and the Family; 1999. Available at: www.mediafamily.org/research/report_radiocontentanalysis.pdf. 
argued that music censorship has limited the creativity of music. However, posterity shows that even positive music can be produced in a creative manner thereby providing moral instruction, promotion of civic duties, entertainment, and financial benefit and having a long time benefit on the youths and society. ${ }^{74}$ Stiffer penalties should be laid on violators of the laws which ban pornography, violence and promotion of drug abuse in music and videos, by ensuring that the punishment is severe enough to create an awareness to deter people from doing so and patronizing such products.

Furthermore, if censorship by regulatory authorities cannot have a total effect in protecting the youths from negative content in music and their video, parents and guardians can further provide censorship in their homes. This censorship would help prevent the youth from patronizing such negative music as long as they belong to a household. ${ }^{75}$ There is also an urgent need for the corporate organizations that endorse musicians and producers of these videos to scrutinize the kind of music their aspiring ambassadors produce and what message they broadcast in their lyrics and videos. What is critical now is that values are being replaced by expediency for wealth and popularity. ${ }^{76}$ There is the need for more advocacies to uphold the tenets of positive contribution to the society by all and sundry. The entertainment industry to which music belongs must also play its role of broadcasting messages that would cause positive change in its video and lyrics. ${ }^{77}$ The interested parties must be made aware that their products can have toxic effects if adequate attention is not made to address any unwholesome content in the music.

Similarly, minors in the society circumvent the law by viewing negative videos via other sources the censor's board have no control over; such as Internet accessed through the computers and mobile phones. Since

74 Recording Industry Association of America, Market Data on Hispanic Consumers and Pre-recorded Music (Washington, DC; 1999) <www.riaa.com/ newsitem.php?news_year_filter=1999\&resultpage=\&id=9D438995-0F74-BCF463F8-5C3920048218> accessed 18 July 2015.

75 See also Bushman BJ, Huesmann LR. Short-term and long-term effects of violent media on aggression in children and adults (Arch Pediatr Adolesc Med.2006; 160 (4):348-352) retrieved from <www.pediatrics.org/> accessed 1 July 2015.

76 See also Chapman AJ, Williams AR. Prestige effects and aesthetic experiences: adolescents' reactions to music. (Br J Soc Clin Psychol.1976;15 (1):61-72) <www.pediatrics.org/> accessed 1 July 2015.

77 See also Roberts DF, Foehr UG, Rideout V. Generation M: Media in the Lives of 8-18 Year-Olds. Menlo Park, CA: Henry J. Kaiser Family Foundation; 2005. Available at <www.kff.org/entmedia/7251.cfm>. 
Nigeria currently lacks the ability to prevent people from streaming negative music online or ban people from downloading the podcasts, the government can place a gag order on such negative Internet sites or impose hefty fines and taxes to deter such people. ${ }^{78}$

Finally, this article advocates that young people should become more selective and critical of contemporary music, and that parents should take a more active role in monitoring their children's listening habits. ${ }^{79}$ This can be done by careful and ardent listening to the lyrics of the music as well as an unbiased viewing of the music video in order to determine its suitability and relevance.

\section{CONCLUSION}

Serious thought must be placed on the kind of influence music artistes have on Nigerian youths and the society at large. Law cannot solely help regulate the appropriateness of music and videos. To transcend the prevailing era of nudity, lewdness and inappositeness in the Nigerian music industry, all stakeholders, across economic, social and legal sectors, have fundamental roles to play, starting from parents and corporate organizations who endorse the makers of these videos, to media houses and religious groups that refer to or offer acceptance to these songs. Regulatory authorities also have to be more proactive in censoring music content to ensure appropriateness.

It is important to ensure that only forms of music that can contribute to sustainable development necessary for the Nigerian youths, is allowed and encouraged to be produced and aired. Music has a high influence on the personality and identity of today's youth. Although not everyone has the same taste in music, conflicting tastes can cause disagreements among people in determining what should be allowed to trend or what should be criticized and banned. This article has discussed social, legal and economic thresholds of appropriateness that could be employed to streamline and review the lyric, video content and promotion of music to ensure appropriateness.

78 See also American Academy of Paediatrics, Committee on Communications. Impact of music lyrics and music videos on children and youth. Paediatrics, 1996;98 (6 pt 1):1219-1221.

79 See also Leming, J.S. Rock music in the socialization of moral values in early adolescence (Youth Soc.1987;18 (4):363-383) retrieved from <www.pediatrics.org/ $>$ accessed 21 July 2015. 